\title{
L-arginine in low concentration improves rat intestinal water and sodium absorption from oral rehydration solutions
}

\author{
R A Wapnir, M A Wingertzahn, S Teichberg
}

\begin{abstract}
Background-The nitric oxide (NO) precursor L-arginine has been shown to produce variable effects on intestinal absorptive function, including ion transport.

Aims-To determine whether there is an optimal concentration of $\mathbf{L}$-arginine, promoting proabsorptive effects from oral rehydration solutions (ORS) with 90 or $60 \mathrm{mM}$ sodium.
\end{abstract}

Subjects and methods-In vivo perfusion of rat jejunum with determination of net water absorption, unidirectional fluid exchanges, sodium and calcium transport, and glucose absorption.

Results-L-Arginine (1 $\mathrm{mM})$ added to the $90 \mathrm{mM}$ sodium ORS increased intestinal absorption of both sodium and water. Higher concentrations of $L$-arginine ( 2 to $10 \mathrm{mM}$ ) lacked this stimulatory effect. At $20 \mathrm{mM}$, L-arginine decreased sodium absorption below baseline. With a $60 \mathrm{mM}$ sodium ORS, $2 \mathrm{mM}$ L-arginine had a maximal fluid and electrolyte proabsorptive effect. At $20 \mathrm{mM}$ L-arginine, net water absorption was indistinguishable from that obtained in the absence of L-arginine, and lower than with $2 \mathrm{mM}$ L-arginine. Sodium absorption remained raised above baseline in perfusions with 10 and 20 mM L-arginine. Morphologically, villi from perfusions with increased absorption showed a large expansion of intercellular and lamina propria intercellular spaces.

Conclusions-Low concentrations of Larginine seem to stimulate water and electrolyte absorption by the small intestine. This effect is consistent with NO induced vasodilation, whereas higher L-arginine concentrations may be vasoconstrictive and thereby reverse fluid and electrolyte transport.

(Gut 1997; 40: 602-607)

Keywords: L-arginine, nitric oxide, oral rehydration solutions, sodium absorption.

Nitric oxide (NO) is known to have multiple physiological roles. ${ }^{12}$ In the gastrointestinal system NO can act as an inflammatory mediator, a regulator of intestinal ion transport, and as an inducer of soluble guanylate cyclase, which effects the relaxation of gastrointestinal smooth muscle. ${ }^{3-5}$ Production of NO contributes to the preservation of vascular integrity in endotoxin generated gut damage. ${ }^{6}$ It has been postulated that endogenous NO regulates the integrity of the intestinal mucosa ${ }^{7}$ and decreases mucosal permeability due to reperfusion injury. ${ }^{8}$

Several studies suggest that NO may have favourable effects on transport in the small intestine during normal and pathophysiological states. NO donor compounds stimulate electrolyte transport in the guinea pig intestine in vitro. ${ }^{9}$ Both L-arginine and the NO donor sodium nitroprusside reduce water and electrolyte secretion in isolated rabbit ileum. ${ }^{10}$ $\mathrm{NO}$ also reduces cholera toxin induced fluid secretion in the rat, as deduced from the systemic administration of L-arginine. ${ }^{11}$ Similarly, inhibition of NO production seems to be beneficial in experimental colitis. ${ }^{12}$ However, under certain circumstances, NO production leads to colonic electrolyte secretion. ${ }^{13}$

The principal physiological precursor of NO is L-arginine, a non-essential amino acid which is metabolically processed by the urea cycle. ${ }^{14}$ The effects of L-arginine are stereospecific, the natural L-isomer being the active form. $\mathrm{NO}$ is synthesised via NO synthase (NOS). Three isozymes have been identified: two constitutive (NOS-I and NOS-III; cNOS) and an inducible form (NOS-II; iNOS). ${ }^{15}$ Known inhibitors of iNOS, such as $\mathrm{N}^{\mathrm{G}}$-nitro-L-arginine methyl ester (L-NAME), are stereospecific. ${ }^{16} \mathrm{~L}$ NAME can also modulate water transport in rat jejunum. ${ }^{17}$ In the intestine it seems as if the dominant effects of NO vary according to the localisation of $\mathrm{NO}$ generators or NO inhibitors.

Oral rehydration solutions (ORS) have undergone numerous modifications in search of a formulation that would be effective in the replacement of water and electrolyte losses in diarrhoea as well as reducing the purging rate, providing a direct inducement for use at home by medically untrained care givers. ${ }^{18}$ Amino acids have been the most often tested low molecular weight additives to experimental ORS. L-alanine, glycine, and L-glutamine have reached the stage of clinical trials. However, results with these amino acids have generally fallen below expectations. Other additives - namely, starch hydrolysates, especially from rice or glucose polymers - have gained greater acceptance and are probably more effective. ${ }^{19-21}$ Because NO may stimulate intestinal water and electrolyte absorption, the addition of the NO precursor L-arginine to ORS is of potential value. The goal of the 
present study was to determine the concentration of L-arginine in ORS that would produce a maximal enhancement of absorption, using a standard in vivo perfusion model in rats.

\section{Methods}

EXPERIMENTAL PROTOCOL

Sprague-Dawley male rats (Zivic-Miller Labs, Pittsburgh, PA, USA) weighing 70 to $90 \mathrm{~g}$ were allowed to acclimatise for at least 48 hours and then fasted overnight before laparotomy. Briefly, under urethane anaesthesia (intraperitoneal, $1.3 \mathrm{~g} / \mathrm{kg}$ ), a $15-30 \mathrm{~cm}$ segment of the jejunum immediately distal to the ligament of Treitz, was identified and cannulated with flexible, plastic tubing at the proximal and distal ports. The experimental ORS described below, prewarmed to enter the perfused segment at $37^{\circ} \mathrm{C}$, were delivered with a peristaltic pump (Harvard Instruments, Boston, MA, USA, model 1203) at a rate of $10-12 \mathrm{ml} / \mathrm{h}$. The precise pumping rate was determined by measuring the rate of flow before and after the perfusion. Approximately $2 \mu \mathrm{Ci} / 1$ (= $74 \mathrm{MBq} / \mathrm{l}, \mathrm{NEN}-$ Dupont, Boston, MA, USA) of tritiated water $\left({ }^{3} \mathrm{H}_{2} \mathrm{O}\right)$ was added to all solutions to determine water influx $\left[\mathfrak{F}_{i}\right]$ from lumen to serosa. Based on previous determinations, the recirculation of the marker was estimated to be negligible during the course of the experiment. Water secretion (serosa to mucosa efflux) $\left[\mathfrak{F}_{e}\right]$ was estimated by calculating the difference between influx and net water absorption. The algorithms applied to compute rates of absorption have been published previously. ${ }^{22}$ Groups of 12 rats were perfused simultaneously, and several solutions were tested in the same experiment to minimise interexperimental variation. The total number of rats used for each treatment appears in the legend of the figures and in the tables. After a one hour equilibration, perfusates were collected for eight 15 minute periods and analysed for net water absorption, unidirectional fluid movement, net sodium absorption, calcium secretion into the perfusate, and glucose absorption. The rate of net water absorption was computed by the formula:

$$
\frac{\text { (Inflow rate }[\mathrm{m} / \mathrm{min}])-(\text { Outflow rate }[\mathrm{m} / \mathrm{min}])}{15(\mathrm{~min}) \times \mathrm{IL}(\mathrm{cm})} \times 1000=\mu / \min \times \mathrm{cm}
$$

The rate of water influx $\left[\mathfrak{F}_{i}\right]$, also expressed in $\mu \mathrm{l} / \mathrm{min} \times \mathrm{cm}$, was calculated as follows:

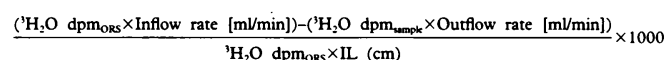

Electrolyte and glucose absorption were computed and expressed in $\mathrm{nmol} / \mathrm{min} \times \mathrm{cm}$ :

$$
\frac{\left.\left([\text { Solute }]_{\text {ORs }} \times \text { Inflow rate }[\mathrm{m} / \mathrm{min}]\right)-([\text { Solute }])_{\text {mpmpk }} \times \text { Outflow rate }[\mathrm{m} / \mathrm{min}]\right)}{\mathrm{IL}(\mathrm{cm})} \times \mathrm{f}
$$

where $\mathrm{IL}=$ intestinal length $(\mathrm{cm}) ; \mathrm{f}=$ dilution factor $\times 1000$.

The assay results of each collection fraction were averaged and only one value was taken for each rat.

Once the perfusion ended, the rats were killed by exsanguination from the abdominal aorta. The intestinal segment between the cannulae was extended with a $4 \mathrm{~g}$ weight and measured. Tritiated water was counted in a Beckman LS-3800 $\beta$-scintillation counter; sodium and calcium were determined by atomic absorption spectrophotometry (SpectrAA 10, Varian Instruments Inc, Sunnyvale, CA, USA) against external standards, and osmolality was measured by vapour pressure changes (Model 5500, Wescor Inc, Logan, UT, USA). Free glucose was determined enzymatically (Sigma 510). Nitrite accumulation in the perfusates was quantified by a method based on the Griess reaction. ${ }^{12}$ The protocol for this study was approved by the Institutional Animal Care and Utilization Committee.

The basal WHO-ORS contained sodium chloride (30 or $60 \mathrm{mM}$ ) and trisodium citrate $(10 \mathrm{mM})$, making a total sodium concentration of either 60 or $90 \mathrm{mM}$, potassium chloride $(20 \mathrm{mM})$ and glucose (111 $\mathrm{mM}=20 \mathrm{~g} / \mathrm{l})$. L-arginine (Sigma, St Louis, MO, USA) was added to the solutions at a $0.5,1 \cdot 0,2 \cdot 0,10 \cdot 0$, or $20 \mathrm{mM}$ concentration. Table I presents the osmolality of the basal and modified ORS. Results are expressed as means (SEM).

\section{LIGHT AND ELECTRON MICROSCOPY}

For study by light and electron microscopy the jejunum was fixed by perfusion through the lumen with $2 \%$ glutaraldehyde in $0.05 \mathrm{M}$ cacodylate buffer $(\mathrm{pH} 7 \cdot 3)$ at room temperature, followed by immersion in the same buffer at $4^{\circ} \mathrm{C}$ for two to 18 hours. The tissue was then rinsed in cold buffer, dissected into well oriented fragments to include regions spanning from the serosal surface to villus tip. Tissue fragments were postfixed in $2 \%$ buffered osmium tetroxide at $4^{\circ} \mathrm{C}$ for two hours, treated with $1 \%$ tannic acid in $0.1 \mathrm{M}$ cacodylate, rinsed in buffer, dehydrated in a series of ethanol dilutions, and embedded in effapoxy resin (E Fullam, Schenectady, NY, USA). One micrometre thick plastic sections, stained with toluidine blue, were examined by light microscopy. Thin sections were studied and stained with uranyl acetate and lead citrate, on a JEOL-JEM 100CXII electron microscope.

Samples from both the $60 \mathrm{mM}$ and $90 \mathrm{mM}$ sodium ORS perfusions were studied by light and electron microscopy in the absence of L-arginine, at the concentration of maximal sodium and water absorption for each ORS and at the highest L-arginine concentration used $(20 \mathrm{mM})$. Light microscopical studies were done "blind" to assess histological differences and to compare the relative amount

TABLE I Mean osmolality ( $\mathrm{mOsm} / \mathrm{kg}$ ) of basal ORS and those containing arginine

\begin{tabular}{lllllll}
\hline \multicolumn{7}{l}{$L$-Arginine $(m M)$} \\
\cline { 2 - 7 } & 0 & 0.5 & $1 \cdot 0$ & $2 \cdot 0$ & $10 \cdot 0$ & $20 \cdot 0$ \\
\hline $90 \mathrm{mM}$ sodium & 307 & 311 & 319 & 324 & 365 & 377 \\
$60 \mathrm{mM}$ sodium & 271 & 276 & 279 & 271 & 296 & 308 \\
\hline
\end{tabular}

The values correspond to two to four measurements per group. 
of tannic acid stained material adherent to the microvillus brush border under the various experimental conditions.

\section{STATISTICAL ANALYSIS}

For transport studies, the significance of the differences among means was assessed by the Kruskal-Wallis test with non-parametric multiple contrasts. ${ }^{23} \mathrm{~A}$ test for trend was applied to determine L-arginine concentration versus dependent variable outcomes. ${ }^{24}$ The minimum level of significance was set at $\mathrm{p}<0 \cdot 05$.

\section{Results}

WATER AND ELECTROLYTE ABSORPTION

The addition of a low concentration of L-arginine enhanced water and electrolyte absorption from both the $90 \mathrm{mM}$ and $60 \mathrm{mM}$ sodium ORS (Figs 1 and 2). When L-arginine was added to the $90 \mathrm{mM}$ sodium ORS at a 1 $\mathrm{mM}$ concentration, there was a significant increase in the absorption of both sodium and water (Fig 1). A lower concentration of L-arginine $(0.5 \mathrm{mM})$ produced no alterations over baseline. An increase in $\mathrm{L}$-arginine concentration to 2 or $10 \mathrm{mM}$ dissipated the stimulatory effect. The addition of $20 \mathrm{mM}$ L-arginine resulted in sodium absorption rates lower than the baseline. For both net water and sodium absorption the uptake at the three highest concentrations of L-arginine was

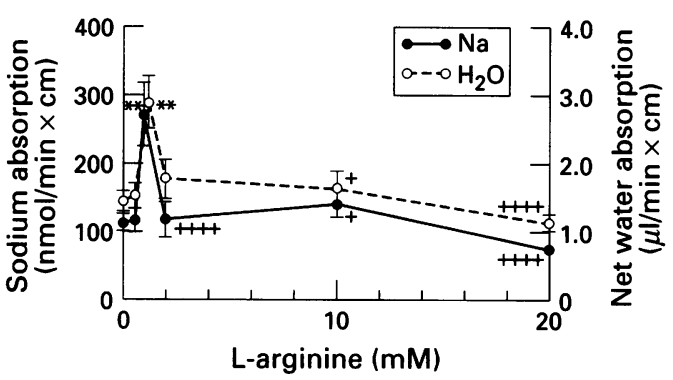

Figure 1: Mean (SEM) rates of sodium and net water absorption during perfusions of $90 \mathrm{mM}$ sodium ORS containing variable concentrations of $L$-arginine. ${ }^{\star} p<0.05$; ${ }_{\star \star *} p<0.01$ compared with $0 \mathrm{mM} L$-arginine. ${ }^{+} p<0.05$; ${ }^{++} p<0.01 ;{ }^{++++} p<0.0001$ compared with maximal absorption rates ( $1 \mathrm{mM} L$-arginine). The number of animals is that shown in Table II.

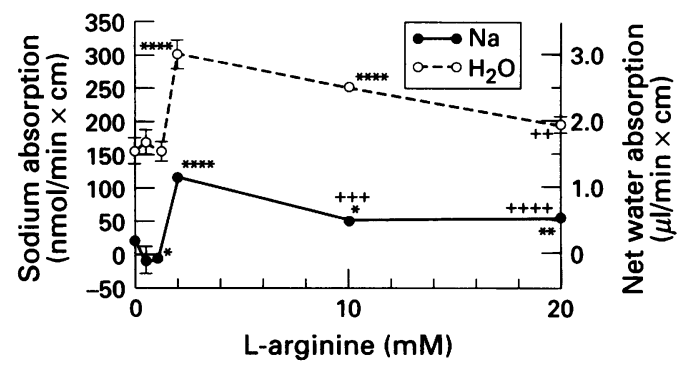

Figure 2: Rates of sodium and net water absorption during perfusions with $60 \mathrm{mM}$ sodium ORS containing variable concentrations of L-arginine. ${ }^{*} p<0.05 ;{ }^{\star}{ }^{*} p<0.01$; $\star \star \star \star p<0.0001$ compared with $0 \mathrm{mML}$-arginine. ${ }^{++} p<0.01 ;^{+++} p<0.001 ;^{++++} p<0.0001$ compared with
(n) maximal absorption rates (2 mM L-arginine). Other features are as in Fig 1. significantly lower than the peak values obtained with the addition of $1 \mathrm{mM}$ L-arginine.

In ORS perfusions containing $60 \mathrm{mM}$ sodium, L-arginine exerted its maximum proabsorptive effect on water and sodium absorption at $2 \mathrm{mM}$ (Fig 2). At this concentration of L-arginine net transport of the electrolyte was absorptive. At lower L-arginine concentrations, the values obtained for sodium transport were indicative of a balance in sodium movement to and from the lumen, with modest mean secretory values at $1 \mathrm{mM}$ L-arginine. Net water absorption at 2 $\mathrm{mM}$ and at $10 \mathrm{mM} \mathrm{L}$-arginine remained higher than baseline. However, when L-arginine was increased to $20 \mathrm{mM}$, net water absorption became indistinguishable from that obtained in the absence of L-arginine, and lower than at the maximum effective concentration of $2 \mathrm{mM}$ L-arginine. Sodium absorption remained higher than baseline in perfusions with $10 \mathrm{mM}$ and $20 \mathrm{mM}$ L-arginine.

\section{WATER FLUXES}

With the $90 \mathrm{mM}$ sodium ORS, $\left[\mathscr{F}_{i}\right]$, as determined by the disappearance of tritiated water, was increased with $1 \mathrm{mM} \mathrm{L}$-arginine and decreased with $20 \mathrm{mM}$ L-arginine, paralleling net water absorption data (Table II). Water efflux $\left[\mathscr{F}_{e}\right]$ also declined with $20 \mathrm{mM}$ $\mathrm{L}$-arginine as well as at $2 \mathrm{mM}$ L-arginine. The ratio $\left[\mathcal{F}_{i}\right] /\left[\mathcal{F}_{e}\right]$ was unaffected by the $\mathrm{L}$-arginine concentration.

In $60 \mathrm{mM}$ sodium ORS perfusions (Table II) $\left[\mathscr{F}_{i}\right]$ increased at $2 \mathrm{mM}$ L-arginine, paralleling net water absorption, and a decline in $\left[\mathscr{F}_{e}\right]$ was evident at $20 \mathrm{mM}$. The $\left[\mathfrak{F}_{i}\right] /\left[\mathscr{F}_{e}\right]$ ratio peaked at $2 \mathrm{mM}$ and remained raised at $10 \mathrm{mM}$ and $20 \mathrm{mM}$ L-arginine. With $2 \mathrm{mM}$ $\mathrm{L}$-arginine, this ratio was greater than at 0.5 $\mathrm{mM}$ and $1.0 \mathrm{mM}$ L-arginine. The trend toward a higher ratio as the concentration of L-arginine increased was consistent with the decline in water $\left[\mathfrak{f}_{e}\right]$. Despite the lower osmolality of the $60 \mathrm{mM}$ sodium ORS, baseline water net absorption, unidirectional fluxes, and flux ratios were indistinguishable from those of the $90 \mathrm{mM}$ sodium ORS.

GLUCOSE, CALCIUM, AND NITRITE STUDIES

L-Arginine, in concentrations ranging from 1 to $20 \mathrm{mM}$, generally stimulated glucose absorption from both the 90 and $60 \mathrm{mM}$ sodium ORS (Table III).

No relation was evident between calcium secretion and water and sodium data. Calcium was secreted under all perfusion conditions, but was greater with $60 \mathrm{mM}$ than $90 \mathrm{mM}$ sodium (Table III). With the $90 \mathrm{mM}$ sodium ORS, calcium secretion was maximal at $20 \mathrm{mM}$ L-arginine. With the $60 \mathrm{mM}$ sodium ORS, calcium secretion was maximal at $10 \mathrm{mM} \mathrm{L}$-arginine. Calcium release into the lumen was about three orders of magnitude smaller than sodium absorption rates. 
TABLE II Unidirectional water fluxes

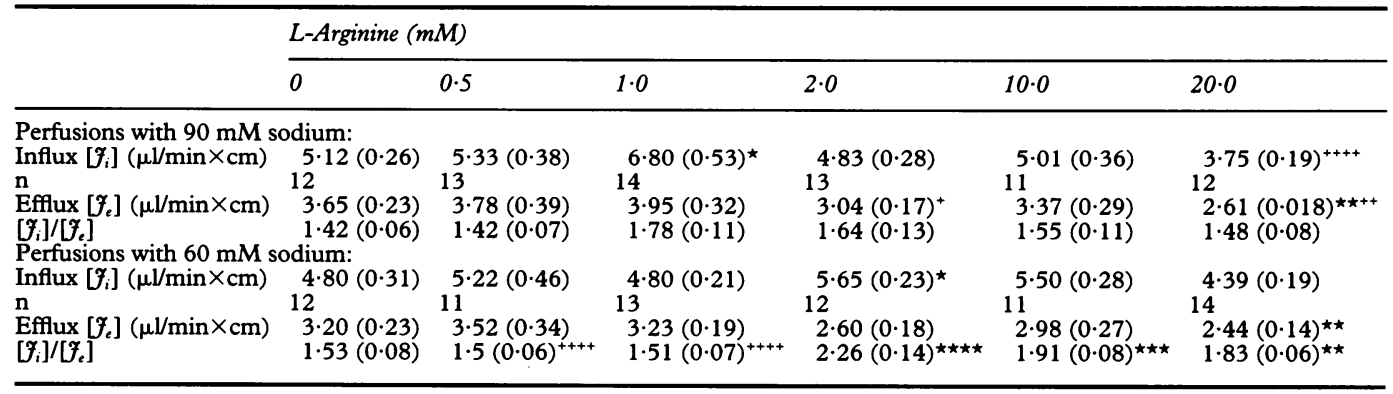

${ }^{\star} \mathrm{p}<0.05 ;{ }^{\star \star} \mathrm{p}<0.01 ;{ }^{\star \star \star} \mathrm{p}<0.001 ;{ }^{\star \star \star \star \star} \mathrm{p}<0.0001 v 0 \mathrm{mM} \mathrm{L-arginine}$

${ }^{+} \mathrm{p}<0.05 ;^{++} \mathrm{p}<0.01 ;^{++++} \mathrm{p}<0.0001 v$ highest value.

Data expressed as means (SEM).

TABLE III Glucose and calcium transport in the presence of L-arginine

\begin{tabular}{|c|c|c|c|c|c|c|c|c|c|c|c|c|}
\hline & \multicolumn{12}{|c|}{ L-Arginine ( $m M$ ) } \\
\hline & \multicolumn{2}{|l|}{0} & \multicolumn{2}{|l|}{0.5} & \multicolumn{2}{|l|}{$1 \cdot 0$} & \multicolumn{2}{|l|}{$2 \cdot 0$} & \multicolumn{2}{|l|}{$10 \cdot 0$} & \multicolumn{2}{|l|}{$20 \cdot 0$} \\
\hline & \multicolumn{12}{|c|}{$[\mathrm{Na}](\mathrm{mM})$} \\
\hline & 90 & 60 & 90 & 60 & 90 & 60 & 90 & 60 & 90 & 60 & 90 & 60 \\
\hline $\begin{array}{l}\text { Glucose } \\
\text { (nmol/min } \times \mathrm{cm}) \\
\text { (n) } \\
\text { Calcium } \\
(\mathrm{pmol} / \mathrm{min} \times \mathrm{cm})\end{array}$ & $\begin{array}{l}39 \cdot 3 \\
(3 \cdot 0) \\
(12) \\
-58 \\
(17)\end{array}$ & $\begin{array}{l}30 \cdot 1 \\
(5 \cdot 6) \\
(12) \\
-198 \\
(24)\end{array}$ & $\begin{array}{l}38 \cdot 1^{++} \\
(4 \cdot 0) \\
(13) \\
-78 \\
(13)\end{array}$ & $\begin{array}{l}27 \cdot 3^{+} \\
(3 \cdot 8) \\
(11) \\
-216 \\
(36)\end{array}$ & $\begin{array}{l}60 \cdot 2^{\star \star} \\
(6 \cdot 5) \\
(14) \\
-80 \\
(18)\end{array}$ & $\begin{array}{l}48 \cdot 9^{\star \star} \\
(5 \cdot 6) \\
(13) \\
-238 \\
(14)\end{array}$ & $\begin{array}{l}55 \cdot 1 \star \star \\
(4 \cdot 4) \\
(13) \\
-131 \\
(39)\end{array}$ & $\begin{array}{l}44 \cdot 0 \\
(3 \cdot 6) \\
(12) \\
-202 \\
(16)\end{array}$ & $\begin{array}{l}58 \cdot 8^{\star \star} \\
(4 \cdot 7) \\
(11) \\
-75 \\
(22)\end{array}$ & $\begin{array}{l}54 \cdot 6^{\star \star \star} \\
(4 \cdot 1) \\
(11) \\
-269^{\star+} \\
(20)\end{array}$ & $\begin{array}{l}59 \cdot 9^{\star \star \star} \\
(3 \cdot 8) \\
(12) \\
-110^{\star \star} \\
(18)\end{array}$ & $\begin{array}{l}50 \cdot 6^{\star \star} \\
(3 \cdot 7) \\
(14) \\
-190 \\
(11)\end{array}$ \\
\hline
\end{tabular}

${ }^{\star} \mathrm{p}<0.05 ;{ }^{\star \star} \mathrm{p}<0.01 ;{ }^{\star \star \star} \mathrm{p}<0.001 ; v 0 \mathrm{mM} \mathrm{L}$-Arginine.

${ }^{+} \mathrm{p}<0.05 ;{ }^{++} \mathrm{p}<0.001 v$ highest value.

Data expressed as means (SEM).

Nitrite measured in the outflow of the perfusates containing $90 \mathrm{mM}$ sodium showed no direct relation with the concentration of L-arginine present. The baseline value of $13 \cdot 3$ (1.6) $\mathrm{pmol} / \mathrm{min} \times \mathrm{cm}$ only increased to $30 \cdot 3$ $(7 \cdot 7) \mathrm{pmol} / \mathrm{min} \times \mathrm{cm}$ at $10 \mathrm{mM}$ L-arginine. Nitrite production and release was not determined in perfusions with $60 \mathrm{mM}$ sodium.

\section{MORPHOLOGICAL FINDINGS}

Light microscopical studies of jejunal villi focused on the extracellular space of villus mucosa and lamina propria histological compartments. Generally, morphological
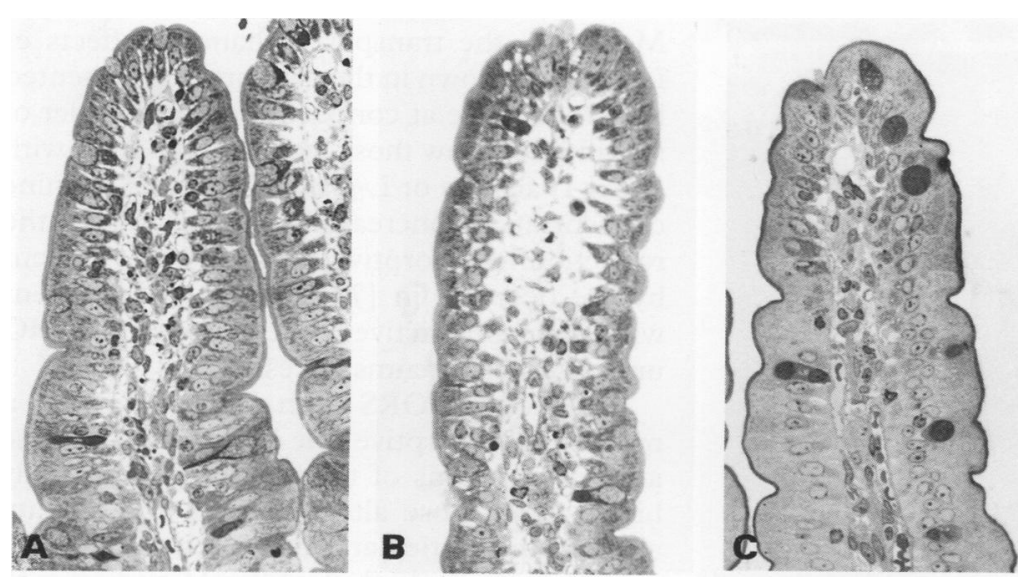

Figure 3: Light photomicrographs of $1 \mu \mathrm{m}$ sections of typical jejunal villi from preparations perfused with a $90 \mathrm{mM}$ sodium ORS without L-arginine $(A)$, with the addition of $1 \mathrm{mM}$ $L$-arginine (B), and with $20 \mathrm{mM} L$-arginine $(C)$. Note the dilation of intercellular spaces between enterocytes on the villus mucosa and of the lamina propria with the $1 \mathrm{mM}$ $L$-arginine $90 \mathrm{mM}$ sodium ORS $(B)$, compared with the L-arginine free perfusion $(A)$. This increase in extracellular space is no longer evident when the L-arginine concentration is raised to $20 \mathrm{mM}$. Originally $\times 450$. changes of jejunal villi reflected L-arginine induced water and sodium transport alterations from perfusion experiments. Jejunal villi perfused with an L-arginine free $90 \mathrm{mM}$ sodium ORS showed some dilation of intercellular spaces between enterocytes and lamina propria (Fig 3A). The addition of $1 \mathrm{mM}$ L-arginine to the $90 \mathrm{mM}$ sodium ORS perfusion led to a greatly increased expansion of the mucosal and lamina propria intercellular spaces, a finding consistent with the stimulation of water and sodium translocation from the lumen across the mucosa (Fig 3B). By contrast, in ORS perfusions with $20 \mathrm{mM}$ L-arginine, mucosal and lamina propria intercellular spaces were reduced and were not readily distinguishable from villi in $\mathrm{L}$-arginine free perfusions (Fig 3C). The pattern of morphological findings with the $60 \mathrm{mM}$ sodium ORS paralleled those seen with $90 \mathrm{mM}$ sodium (Figs 4A, B, and C). With the $60 \mathrm{mM}$ sodium ORS, intercellular space expansion was most evident at $2 \mathrm{mM} \mathrm{L}$-arginine (Fig 4B), but was reduced in jejunum perfused with 20 mM L-arginine (Fig 4C).

There was no evidence of structural damage to jejunal villi, or of changes in the number of goblet cells under any of the perfusion conditions. The amount of tannic acid positive material adherent to the brush border varied between animals, but no effect produced by the differing L-arginine perfusion conditions was distinguishable. When examined by electron microscopy villus absorptive cells from $90 \mathrm{mM}$ and $60 \mathrm{mM}$ sodium ORS perfusions were normal in appearance and unaltered by the addition of L-arginine at the concentration producing maximal proabsorptive effect (Figs $5 \mathrm{~A}$ and $\mathrm{B})$. 

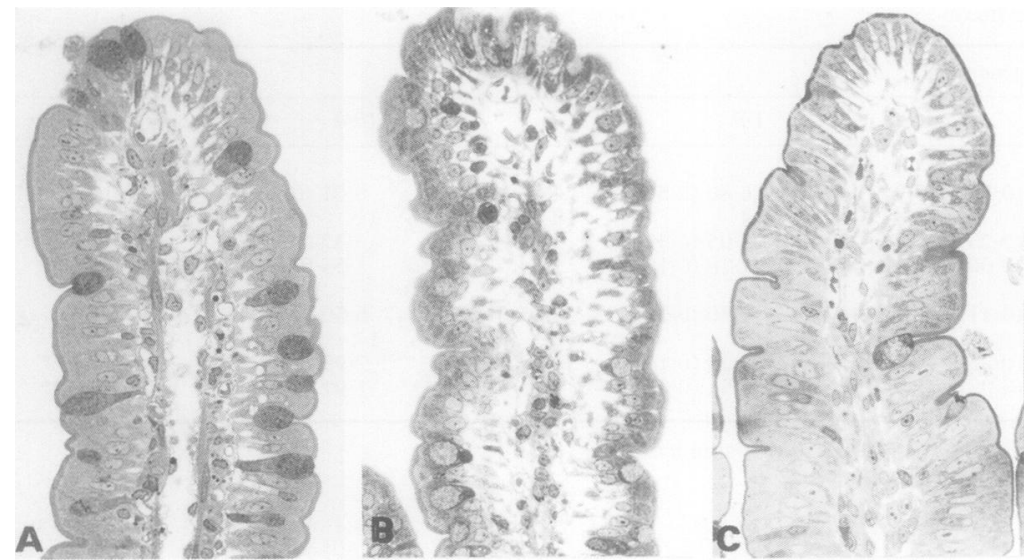

Figure 4: Light photomicrographs of typical jejunal villi perfused with a $60 \mathrm{mM}$ sodium $O R S$, with no added L-arginine $(A)$, with $2 \mathrm{mM} L$-arginine $(B)$, and with $20 \mathrm{mM}$ $L$-arginine $(C)$. The pattern of changes in the amount of mucosal and lamina propria intercellular space is similar to that seen with the $90 \mathrm{mM}$ sodium ORS. With the $60 \mathrm{mM}$ sodium ORS, dilation of the intercellular spaces on the villus mucosa and lamina propria is most pronounced in $2 \mathrm{mM} L$-arginine perfusions (B). The expansion of the extracellular spaces is then reduced when L-arginine is perfused at $20 \mathrm{mM}(C)$. Originally $\times 450$.

\section{Discussion}

The results indicate that the addition of relatively low concentrations of L-arginine (1-2 $\mathrm{mM})$ to an ORS can induce positive increments in the rates of sodium and water absorption, when tested in an in vivo jejunal perfusion system in the rat. This effect was seen in ORS with $90 \mathrm{mM}$ as well as $60 \mathrm{mM}$ sodium. These physiological transport data were paralleled by morphological studies

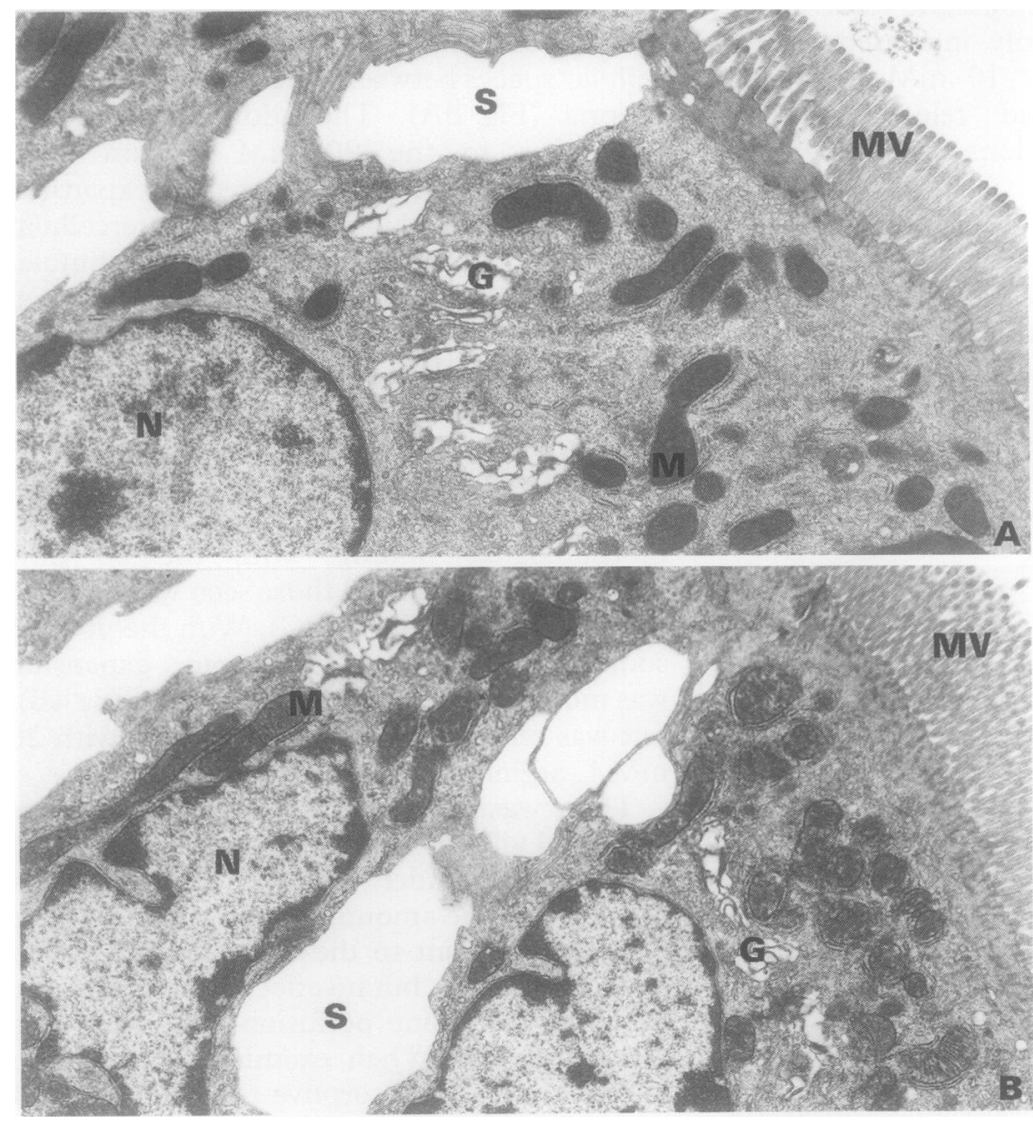

Figure 5: Electron micrographs of portions of absorptive epithelial cells from jejunal preparations perfused with $1 \mathrm{mM}$ L-arginine in a $90 \mathrm{mM}$ sodium ORS (top, $A$ ) and $2 \mathrm{mM}$ $L$-arginine in a $60 \mathrm{mM}$ sodium ORS (bottom, B). There is no evidence of damage to the organelles of the absorptive epithelium. Microvilli (MV), mitochondria(M) and Golgi apparatus $(G)$, all appear intact. Nucleus is at $(N)$. The dilated lateral intercellular spaces are at $(S)$. A originally $\times 13300, B$ originally $\times 11000$. showing expansion of the intercellular spaces after perfusion with low concentrations of L-arginine, a finding consistent with increased water and electrolyte absorption.

By contrast with the present data, earlier studies with L-arginine indicated induction of water secretion in the rat small intestine. ${ }^{172526}$ However, those secretory effects occurred at a relatively high $(20 \mathrm{mM})$ concentration of the amino acid; lower L-arginine concentrations were apparently not tested. In the present study, increasing the concentration of Larginine to $20 \mathrm{mM}$ also produced a decrease in electrolyte absorption with the $90 \mathrm{mM}$ sodium preparations. These results are comparable with those reported earlier with a glucose free solution containing $140 \mathrm{mM}$ sodium. ${ }^{172526}$ It should be noted that Larginine retained its proabsorptive effect up to a $10 \mathrm{mM}$ concentration when the ORS contained $60 \mathrm{mM}$ sodium. The enhancement of sodium uptake from the $60 \mathrm{mM}$ ORS was remarkable in that it greatly exceeded the equilibrium point for sodium transport into the jejunum, which is in the $60-65 \mathrm{mM}$ range, as documented in rodent ${ }^{27}$ and human studies. $^{28}$

Amino acids generally tend to increase water and sodium absorption in the small intestine, as a consequence of the sodium cotransport mechanism involved in the translocation of many natural amino acids across epithelia. This explanation is not tenable for L-arginine for several reasons. In the present study the effect of this amino acid was not concentration dependent, whereas a dose-response relation with water and electrolyte absorption has been found in animal experiments with L-alanine and L-glutamine in animals ${ }^{29-31}$ and in humans. ${ }^{2032}$ The sodium cotransport linkage is also not applicable, as the $y^{+}$system involved in L-arginine transport is considered to be a facilitated diffusion process dependent on a differential in membrane potential. ${ }^{14}$ Amino acids are not uniformly proabsorptive. Glycine, initially postulated as a stimulatory additive, is ineffective at high concentrations; this is probably due to inappropriate sodium : amino acid stoichiometry and increased osmolality. ${ }^{33}$ Moreover, the transport enhancing effects of L-arginine shown in the experiments presented here took place at concentrations one order of magnitude below those attempted in trials with either L-alanine or L-glutamine. As L-arginine concentration increased to $20 \mathrm{mM}$, the reduction in absorptive capacity made evident by the decrease in $\left[\mathscr{F}_{i}\right]$ and $\left[\mathscr{f}_{e}\right]$ is consistent with vasoconstrictive effects linked to NO under certain circumstances.

Perfusion of ORS with L-arginine had a modest proabsorptive role in regard to glucose at concentrations of the amino acid generally higher than those altering water and sodium absorption, particularly in perfusions with 60 $\mathrm{mM}$ sodium. As both the $90 \mathrm{mM}$ and $60 \mathrm{mM}$ sodium ORS contained $111 \mathrm{mM}$ glucose $(20 \mathrm{~g} / \mathrm{l})$, the overriding proportion of the transport is likely to occur by solvent drag. Therefore, this result is compatible with glucose entry into the enterocyte after water 
movement with rapid removal into the circulation.

Calcium is normally secreted into the intestinal lumen during perfusions with solutions which do not contain this element. Whereas the presence of citrate in the ORS in our study may impair calcium absorption, it does not alter secretion of the cation. ${ }^{34}$ In solutions which omit calcium, such as those used in these experiments, a leakage of this cation into the lumen as sodium enters the cell is therefore expected, and consistent with sodium-calcium exchange across membranes. ${ }^{35}$ This was clearly the case here, although no correlation was found between water or sodium absorption and calcium secretion. Osmolality may also play a part in this process, as secretory rates of calcium were higher in experiments with $60 \mathrm{mM}$ sodium than with $90 \mathrm{mM}$ sodium. In view of these results it cannot be argued that a calciumsodium exchange is putatively modulated by NO.

The present experimental model has been extensively used in previous investigations intended to compare the effectiveness of ORS with variable concentrations of solutes, osmolality, or additives, with the ultimate goal of improving their effectiveness in sodium transport and water retention in humans. 27293037 Positive ORS studies on rodents ${ }^{38}$ have subsequently been applied to clinical trials, especially in infantile diarrhoea of various aetiologies. In a clinical study, ${ }^{39}$ the ORS which best reduced stool volume in infants and children with diarrhoea was the same which produced the highest rates of water absorption in the rat. Similarly, the greatest decrease in sodium losses in the faeces paralleled maximal sodium experimental absorption rates in the experimental model.

We thank Mr Jeffrey Moyse for his assistance in the preparation of photographic material. This work was supported in part by a National Institutes of Health (USA) grant HD29255.

1 Marletta MA Nitric oxide: biosynthesis and biological significance. Trends Biol Sci 1989; 14: 488-92.

2 Anggard E. Nitric oxide: mediator, murderer and medicine. Lancet 1994; 343: 1199-206.

3 Ignarro LJ. Biological actions and properties of endothelium-derived nitric oxide formed and released from artery and vein. Circ Res 1989; 65: 1-21.

4 Stark ME, Szurszewski JH. Role of nitric oxide in gastrointestinal and hepatic function and disease. Gastroenterology 1992; 103: 1928-49.

5 Mayer B. Regulation of nitric oxide synthase and soluble guaninyl cyclase. Cell Biochem Funct 1994; 12: 166-77.

6 Hutcheson IR, Whittle BJR, Boughton-Smith NK. Role of nitric oxide in maintaining vascular integrity in endotoxin-induced acute intestinal damage in the rat. $B r$ ₹ Pharmacol 1990; 101: 815-20.

7 Raul F, Galluser M, Schleiffer R, Gossé F, Hasselman M, Seiler N. Beneficial effect of $\mathrm{L}$-arginine on intestinal epithelial restitution after ischemic damage in rats. Digestion 1995; 56: 400-5.

8 Alican I, Kubes P. A critical role for nitric oxide in intestinal barrier function and dysfunction. Am f Physiol 1996; 270: G225-37.

9 MacNaughton WK. Nitric oxide-donating compounds stimulate electrolyte transport in the guinea pig intestine in vitro. Life Sci 1993; 53: 585-93.

10 Barry MK, Aloisi JD, Pickering SP, Yeo CJ. Nitric oxide modulates water and electrolyte transport in the ileum. Ann Surg 1994; 219: 382-8.
11 Turvill JL, Farthing MJG. Nitric oxide (NO) mediates cholera toxin (CT)-induced secretion in rat small intestine in vivo. Gastroenterology 1996; 110: A368.

12 Hogaboam CM, Jacobson K, Collins SM, Blennerhasset MG. The selective beneficial effects of nitric oxide inhibition in experimental colitis. Am f Physiol 1995; 268: G673-84.

13 Tamai H, Gaginella TS. Direct evidence for nitric oxide stimulation of electrolyte secretion in the rat colon. Free Radical Research Communications 1993; 19: 229-39.

14 Cynober L, Le Boucher J, Vasson M-P. Arginine metabolism in mammals. Nutr Biochem 1995; 6: 402-13.

15 Kerwin JF Jr, Lancaster JR Jr, Feldman PL. Nitric oxide: a new paradigm for second messengers. $f$ Med Chem 1995; 38: 4343-62.

16 Moncada S, Higgs A. The L-arginine-nitric oxide pathway. N Engl f Med 1993; 329: 2002-12.

17 Mourad FH, O'Donnell LJD, Andre EA, Bearcroft CP, Clark ML, Farthing MJG. Effect of local and systemic administration of $\mathrm{L}$-arginine and nitro $\mathrm{L}$-arginine methyl ester (L-NAME) on water transport and histologic changes in rat jejunum. Gastroenterology 1995; 108: A309.

18 Avery ME, Snyder JD. Oral therapy for acute diarrhea. The underused simple solution. N Engl f Med 1990; 323: $891-4$.

19 Sarker SA, Majid N, Mahalanabis D. Alanine- and glucosebased hypo-osmolar oral rehydration solution in infants with persistent diarrhoea: a controlled trial. Acta Paediatr with persistent diarrhoea:

20 Bhan MK, Mahalanabis D, Fontaine O, Pierce NK. Clinical trials of improved oral rehydration salt formulations: a review. Bull WHO 1994; 72: 945-55.

21 Goldberg ED, Saltzman JR. Rice inhibits intestinal secretions. Nutr Rev 1996; 54: 36-7.

22 Go JT, Harper RG, Sia CG, Teichberg S, Wapnir RA. Oral rehydration solutions: increased water and sodium absorption by addition of a viscosity-enhancing agent in a rat model of chronic osmotic diarrhea. $\mathcal{f}$ Pediatr Gastroenterol Nutr 1994; 19: 410-6.

$23 \mathrm{Zar} \mathrm{JH}$. Biostatistical analysis. 2nd edn. Englewood Cliffs, NJ: Prentice-Hall, 1984: 185-205.

24 Cuzick J. A Wilcoxon-type test for trend. Stat Med 1985; 4: $87-90$.

25 Mourad FH, Andre EA, O'Donnell LJD, Bearcroft CP, Clark ML, Farthing MJG. L-arginine and intestinal water secretion: is nitric oxide the missing link? Gastroenterology 1994; 106: A256.

26 Mourad FH, O'Donnell LJD, Andre EA, Bearcroft CP, Owen RA, Clark ML, Farthing MJG. L-Arginine, nitric oxide, and intestinal secretion: studies in rat jejunum in vivo. Gut 1996; 39: 539-44.

27 Lifshitz F, Wapnir RA. Oral hydration solutions: experimental optimization of water and sodium absorption. F Pediatr 1985; 106: 383-9.

28 Gisolfi CV, Summers RW, Schedl HP, Bleiler TL. Intestinal water absorption from select carbohydrate solutions in humans. $\Im$ Appl Physiol 1992; 73: 2142-50.

29 Wapnir RA, Zdanowicz MM, Teichberg S, Lifshitz F. Oral hydration solutions in experimental osmotic diarrhea: enhancement by alanine and other amino acids and oligopeptides. Am $\mathcal{F}$ Clin Nutr 1988; 47: 84-90.

30 Wapnir RA, Zdanowicz MM, Teichberg S, Lifshitz F. Alanine stimulation of water and sodium absorption in a model of secretory diarrhea. $\mathcal{f}$ Pediatr Gastroenterol Nutr 1990; 10: 213-21.

31 Rhoads JM, Keku EO, Quinn J, Woosley J, Lecce J. L-glutamine stimulates jejunal sodium and chloride absorption in pig-rotavirus enteritis. Gastroenterology 1991; 100: 683-99.

32 Bhan MK, Chea Woo E, Fontaine O, Maulen-Radovan I, Pierce NF, Ribeiro H Jr. Multicentre evaluation of reduced osmolality oral rehydration salts solution. Lancet 1995; 345: 282-5.

33 Bhan MK, Sazawal S, Bhatnagar S, Bhandari N, Guha DK, Aggarwal SK. Glycine, glycyl-glycine and maltodextrin based oral rehydration solution. Acta Paediatr Scand 1990; 79: $518-26$.

34 Rümenapf G, Schwill PO. The influence of citrate on the duodenal absorption of calcium in the rat. Calcif Tissue Int 1988; 42: 326-30.

35 Donowitz $\mathrm{M}$. $\mathrm{Ca}^{2+}$ in the control of active intestinal $\mathrm{Na}$ and $\mathrm{Cl}$ transport: involvement in neurohormonal action. $\mathrm{Am}$ f Physiol 1983; 245: G165-77.

36 Blaustein MP, Goldman WF, Fontana G, Krueger BK, Santiago EM, Steele TD, Weiss DN, Yarowski PJ. Physiological roles of the sodium-calcium exchanger in nerve and muscle. Ann NY Acad Sci 1991; 639: 254-74.

37 Wapnir RA, Teichberg S, Go JT, Wingertzahn MA, Harper RG. Oral rehydration solutions: enhanced sodium absorption with gum arabic. $\mathcal{F}$ Am Coll Nutr 1996; 15: 377-82.

38 Wapnir RA, Litov RE, Zdanowicz MM, Lifshitz F. Improved water and sodium absorption from rice syrup solids-based oral rehydration solutions in a rat animal model of osmotic diarrhea. $\mathcal{F}$ Pediatr 1991; 118: S53-61.

39 Pizarro D, Posada G, Sandi L, Moran JR. Rice-based oral electrolyte solutions for the management of infantile diarrhea. NEngl f Med 1991; 324: 517-21. 